\title{
Rehabilitation and adaptive reuse of historic buildings in Poland
}

\author{
E. D. Ryńska \\ Faculty of Architecture, Warsaw University of Technology, Poland
}

\begin{abstract}
The functional and urban layout of Polish cities was, and still is, highly influenced by various economic policies. This process may be further supported by the growth of the construction investment sector, as well as globalization and participation of the corporate capital in city investments. In view of this, revitalization and rehabilitation is a very complex process, and as such, it requires application of precise and interdisciplinary procedures. Hence, when analyzing any urban city structure - its physiognomy changing within time and space, we have to include all elements such as: industrial development, inhabitants, type of existing public institutions, natural environment and human habitat. This analysis should start with the distinguishing of functional characteristics - individual features - street and square layout, existence of commercial streets and building structures with city function making elements, existence of historic zones as well as green areas.

It is also quite true that these procedures develop more smoothly in cities which have maintained traditional area divisions. These areas have a historic location and must be analyzed as a single, undivided area, both from the planning as well as from the residents' participation point of view. As a rule, an inventory of urban areas in Poland shows that even downtown there are many zones with low quality structures which should be replaced. The process of replacement allows for protection of the existing green areas, and supports the execution of harmonious complexes.

This paper will be dedicated to three examples: a redevelopment of an Old Brewery complex in Poznan, a replacement of urban tissue in the center of Warsaw, and revitalization of a historic building complex located in Cracow into a hotel. Each of those cases show a different approach, yet each of them show that eco-solutions may be used within adaptive reuse of historic districts.
\end{abstract}

Keywords: contemporary urban landscape, revitalization, industrial zones. 


\section{Introduction}

Environment inhabited by humans can be described as a sequence of places and spaces, changing and merging within the continuum of Time. The last decades of the former century as well as the early years of the $21^{\text {st }}$ Century have brought forth several additional issues - these being a rapid development of industrial areas which for many reasons have become part of the contemporary downtown city landscape, becoming a historic canvas both blending and encroaching upon new architectonic solutions. This phenomenon is characteristic to many large cities - including those located in Poland.

The idea of Eco-Architecture is by no means a new concept. It was born simultaneously with the vernacular Architecture of many regions and has most in common with the access to local building materials, climatic conditions as well as landscape features. As it has been accepted by architectural researchers, the concept of vernacular solutions was in fact halted with the birth of industrialization and the evolvement of new philosophic and technical ideas. Wide access to a seemingly economic transport, worldwide application of reinforced concrete, steel and glass elements - meant that the Architecture became unanimous throughout the world. Low energy features, use of local materials and climatic conditions became secondary issues in the strong drive towards the novelty - a demand for new technical solutions, with high disregard for any other issues allowing for a typical building utilization.

The first eco-, passive and sustainable trends appeared in the '70-ties, later to be developed on the base of a wide knowledge on pollution produced by human civilization, as well as access to education disclosing the issue that the once - as it was assumed - source of plentiful resources, was in fact a very limited amount of resources. Even such elements as air and water - also became known as a scarcity.

Hence, a new approach to the building industry appeared. This consisted of two main areas of interest - one being a new strategy to the new building construction process, the other - giving life to a new approach towards existing old cities, disclosing high cultural values of the existing heritage. Those approaches also varied depending especially on the policies accepted in various countries. Still, even there - approaches had a lot in common. For those countries which were run by Communistic regime, the idea of the past and Vernacular Architecture (as understood: Bourgeois) was considered as something to be entirely wiped out. Existing valuable historic complexes became dilapidated ruins; beautiful examples of industrial architecture became run down volumes devoid of any function. Residential complexes were destroyed to make more place for "the Modern Architecture".

Presently, while thinking about a contemporary city, we usually perceive certain landscapes - Paris - is the life in the small cafés, New York - is the Manhattan, Rome - is the Coliseum.... And yet most of the contemporary cities cover large differentiated areas. Hence, our idea of a certain city may be correct - but only if limited to a specific area - usually a historic center. The identity of a city is formulated by the public spaces, and these are located predominantly in 
the historic centers containing the main values. Each city has a place or a space to boast of. Places where we walk each day or visit as tourists, areas bringing a deeper reflection, awakening emotions and forming a mosaic - not as uniform as once - a picture of our world. A special role is played thus by the public spaces which form a certain "genetic code" of the city, according to which rebuilding from devastation or degradation should be performed (Bielecki [1]). Each generation appoints different meanings to many places - historic centers and the main public areas. These, are unique and have high identity values, felt especially by the inhabitants of the city. Cultural uniformity and surrounding architecture give residents a feeling of continuity, integration and social acceptance.

The contemporary city became a collection of various, loosely connected elements, including public spaces of various types. The traditional city - the historic center - became just one of many components of the city organism. Hence, it is required to distinguish "a city space", from a space "rich" in memories with a cultural background. it should be remembered that "the past" is always imbedded in the buildings, historic monuments and places - shaping our sensitiveness and imagination. It is likely that within the consciousness of the local inhabitants, subconscious cultural values characteristic to that group, such as history, personal or generation experiences, characteristic names describing the place or region of living etc. will be found. Regional identity in connection with the individual and cultural identity is constituted by existing buildings and urban layouts. Hence, the basic attributes of the identity are: the history, tradition of a places, unusual forms, other values (including unique features), existence of green areas, and the "magic" of a place.

The functional and urban layout of the Polish cities was, and still is, highly influenced by the transformations of the various economic policies. This process may be further supported by the growth of the construction investment sector, as well as globalization and participation of the corporate capital in the city investments. In view of this, revitalization is a very complex process, and as such, it requires precise and interdisciplinary procedures. The political circumstances which inspire the start of this process and the technical state of the existing urban tissue are also very important. Hence, when analyzing any urban city structure - its physiognomy changing within time and space, we have to include all elements such as: industrial development, inhabitants, type of existing public institutions, natural and human habitats. This analysis should start with distinguishing of functional characteristics - individual features street and square layout, existence of commercial streets and building structures with city function making elements, existence of historic zones as well as adequate green areas. If the conclusion is, that the prevailing development is based on economy requirements instead of a co-operation process between the economic and other issues, then a following checking procedure should be followed:

$>$ the development of the existing external technical media network, more than often not constructed only in the places where the development is already taking place; 
$>$ location of large commercial developments - presently, closer and closer to the city centers, what follows - is a higher traffic density and additional parking problems;

$>$ logistic abilities and the effective performance level of the conflict solving government city bodies - usually the outcome of undefined division of decision making between different departments.

It is also quite true that the revitalization procedures develop more smoothly in the cities which have maintained the traditional area divisions and developed them as smaller independently managed zones. These areas have a historic location and must be analyzed as a single, undivided area, both from the planning as well as from the residents' participation point of view. As a rule, inventory of the urban areas in Poland shows that even the downtown there are many non-invested zones with low quality structures which should be replaced. The process of replacement allows protects the existing green areas, and supports the execution of harmonious complexes. What areas should be revitalized? Large urban spaces and historic axes layouts. Areas with high cultural values. Those areas merge creating synergy values to be maintained at all costs. Secondly - the city silhouette. Presently a new kind of a high-rise skyline, similar to that found in large Western Europe agglomerations, is emerging in most of the large Polish cities. It should be added that such areas should be rigorously controlled, composed and limited to certain areas only. Thirdly - the degraded areas such as large residential complexes of prefabricated buildings dating from the ' 70 -ties of the $20^{\text {th }}$ Century, downtown historic areas with $19^{\text {th }}$ and early $20^{\text {th }}$ Century structures, railway and military areas as well as post industrial areas.

This paper will be dedicated to three examples: a redevelopment of an Old Brewery complex in Poznan, a replacement of urban tissue in the center of Warsaw, and revitalization of a historic building complex located in Cracow into a hotel. The main issue to be discussed being the non-existence of clear indications, neither properly defined conditions as to how such areas should be developed and revitalized. This process often ends with arguments between the potential developers, historic preservation officers and other city authorities.

\section{Case studies}

Case number one, (Fig. 1) is a complex of old brewery buildings located in the very heart of Poznan; revitalization process created "a new city within a city" since the Old Brewery has everything - shops, restaurants, cafeterias, offices, a gallery and a tower clock with chimes. Above all it has history... In mid $19^{\text {th }}$ Century, Ambrosius Hugger, a beer master brewer from Wirtensberg arrived in Poznan. Twenty years later his sons started to build, the later largest of the Poznań breweries - Hugger Brewery. It is not quite known, when the Huggers bought the plot, but the first building appeared in 1876. The Brewery existed until the end of the First World War. During that time it became a Share Holding company producing a variety of light, dark and porter beers. After the First World War Brewery was sold to a Polish business man, and later, after the 
economic crisis of the '30-ties, leased out to Restaurants Share Holders. In September 1939, Brewery once more became the property of the Germans and produced beer until 1944.

After the Second World War, it was taken over by the government owned Beer Factories, which closed in 1980. No further development took place until the end of the '90-ties, when the estate was purchased by a Polish businesswoman, who decided to revitalize the whole complex and adjoining sites. Design was prepared by a team of Polish Architects - Studio ADS. Brewery buildings were revitalized in phases - 2003-2007. The main part - the Court of Art - was opened already in 2004 and was awarded the title of "The best retail gallery in Europe" and "The best retail gallery in the World" - in the middle size retail gallery class. The works are still being conducted. Now the surrounding park is being revitalized, a boutique hotel is also foreseen. Characteristic to this case is adaptive reuse of existing industrial buildings as well as building found on-site materials and provision of a harmonious design of new volumes creating a small city complex within an urban city quarter. Such systems as stack and dual ventilation systems we applied. Most of the equipment used has low energy parameters.

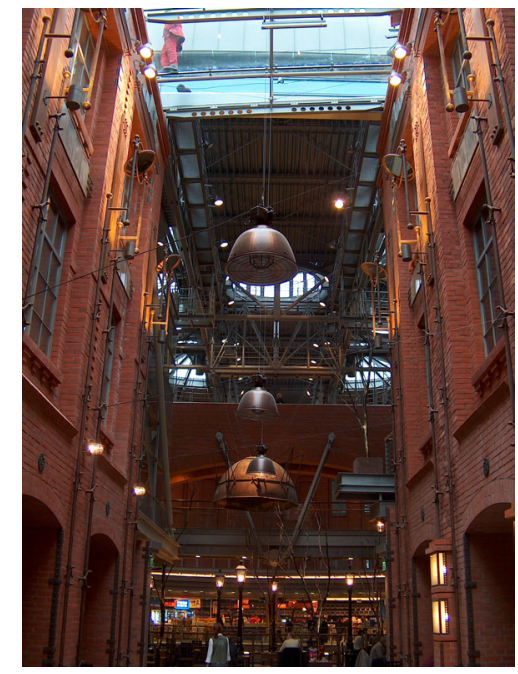

Figure 1: Interior of the Old Brewery, Poznań.

Case number two is located in the down-part of Warsaw, the capital of Poland. This city was to a high degree destroyed during the Second World War. Nevertheless, some residential early $20^{\text {th }}$ Century complexes were left intact. As in other Polish cities, such complexes were not maintained and became to be inhabited by the poorest. After 40 years of neglect, in most cases the only possible solution was to demolish them entirely and construct new volumes. This approach was undertaken when choosing a site for a modern Golden Gallery located in Zlota Street. Remaining 5 story high residential buildings were totally 
erased. In their place, an American and British team of designers developed a public space covered with a characteristic glass canopy. A place which is presently becoming a focus meeting point for many Warsaw inhabitants. Unfortunately, the design did not evolve neither on the existing surrounding buildings, nor did it maintain old atmosphere or features of the former complex.

It is an efficient, modern complex housing a retail gallery, cinemas, food courts and restaurants as well as a large office building. It has such environmental features as stack and dual ventilation systems. Environmental friendly building and finishing materials have been used in many places. It has an internal, glass covered courtyard where the building are perceived like "toys" placed within a larger volume maintaining comfortable parameters. For all its modern outlook and certain eco-solutions, this building is not perceived as part of the continuity of the surrounding environment, which should be one of the aims of such edifices.

Case number three (Fig. 2) is a hotel located in a picturesque Renaissance street at the foot of the Kings Castle - one of the oldest streets in Cracow. Between other - renaissance buildings, this Gothic building at no 16, stands out in a very distinctive way. Its history is as old as the history of the very street. Once it used to belong to the Cathedral Chapter, whose members were at the time the intellectual and financial elite of Poland. Renovation has allowed each of the rooms to have the highest of standards including individual historic decoration. In many places it is possible to find traces of the building's history which have been carefully maintained and restored.

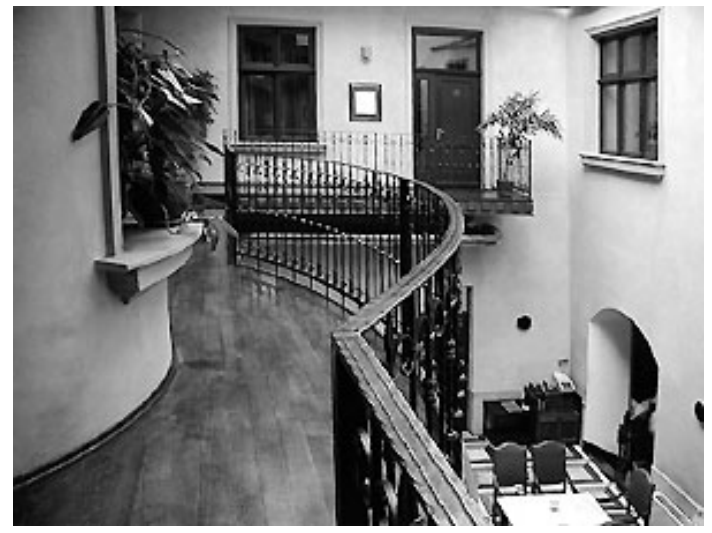

Figure 2: Internal courtyard - Hotel Copernicus, Cracow.

Unique polychromes (dating from 1500) were uncovered during modernization works, as well as timber decorated floors and stone mosaics.. At the moment each of those elements is used as distinctive features of the most prized hotel apartments. This reminiscent discoveries exist in accord with modern solutions - a glass roof over internal courtyard, a panoramic elevator or a sauna in the basement- once a wine cellar. 
Cracow was one of the few cities in Poland not destroyed during the Second World War onslaught. Unfortunately the policy of 1945-83 was directed to construct new buildings without any consideration for the old ones. Hence, the plot at no 16 which was invested already in the first decade of $14^{\text {th }}$ Century became a ruin. Its history forgotten, whereas already by mid $14^{\text {th }}$ century two individual buildings have been constructed on the very plot. Beginning of $15^{\text {th }}$ Century, a church nobleman build a small palace, which burned down and was rebuild some years later. In $19^{\text {th }}$ Century, building was taken over by Austrian army and later sold to secular people. It became totally devastated in the second half of the $20^{\text {th }}$ Century.

This palace, is a wide two storey building with a basement. A seven-axial elevation discloses complex history of the structure. It is possible to find stonework dating back to first half of $14^{\text {th }}$ century, masonry walls from $15^{\text {th }}$ Century with stone window and door frames, remains of large Renaissance pointed windows and a stone gate framework date back to 1554 .

This case building has a set of rooms in the front and back of the plot, joined by side wings and presently covered with a glass canopy. Many historic paintings, decorative details and building solutions - including a complex of 9 timber ceilings dating back to 1450 - were discovered during the restoration which started in 1998.

In this case, adaptive reuse of existing buildings as well as building, found on-site, materials and provision of a harmonious design of new volumes allowed to maintain buildings old character and include modern convenient solutions.

\section{Conclusions}

One of the conclusions arising from the above cases is a fact that contemporary Polish urban designers more than often cannot create a public space sufficiently safe and attractive to compete with the traditional solutions. More than often, the designers and especially the commercial developers try to form a synthesis of a traditional space - an illusion, and since trade and the spending of free time in traditional public spaces has become either too dangerous or not very attractive a substitute has been formulated. Both the architectonic form and urban planning have also become commercialized - and the appearance of theming is due to direct transposition of the designed forms into spaces creating economic gains retail galleries, thematic parks, offices or residential areas. The culture becomes one of the products [9]. A similar process can be perceived in the creation of urban spaces. In effect, new fashions and habits are formed - such as going out to large retail areas, shopping in revitalized down town centers, renewal of local identities through organizing various cultural fairs and life recreation of events. The Eco-aims seem to be much too often entirely forgotten or treated as an additional value that might draw in potential clients.

At the same time maintaining of the historic location and urban layout of a city is one of the most important features for the cultural identity of a city. Hence, a place is only a fragment of a cultural space, which was given consciously or subconsciously certain meanings during the course of its creation. 
Yet in order to understand the meaning of a building, street or a square, we have to understand a certain "code", a language set forth in a very material form. This "language" is also part of the cultural background for people belonging to a certain type of civilization and is part of our national heritage. Due to its existence, the meaning of forms is understood even without any additional historic knowledge. This "principle" - sometimes is described as genius loci "spirit of a place" - something that is presently often entirely lost.

Presently, in order to maintain and revitalize the identity of a place, and feeling of social belonging - various different features are being used. Through this the designers try to find a connection with certain cultural codes positively perceived by the potential clients or users. In effect, new identification forms are being created for groups or places, more than often they copy only certain characteristic features and are more like "a pastiche" than reality. The condition to achieve egalitarian landscape values should therefore be treated as the basic criteria in the present city development [12]. Analogous phenomena takes place during execution of plans for the revitalization of historic complexes. Within the process of the urban regeneration a new definition of cultural landscape is being formulated. This further means that the existing requirements and identity of inhabitants residing in the areas where new elements are introduced may be disrupted, since proposed solutions are foreign to the existing architectural traditions. Hence the long and short term development policy for such areas should be managed according to the following conditions:

$>$ distribution and concentration network of the investment developments in the city areas applied according to the public and private interest criteria (attractiveness for the investors, required visual effects in the city sky-line and correct relations between various city functions, an aim to create "a single whole", rather than "dispersed investment isles");

$>$ application of procedures to create the investment making environment - construction fill-ins, use of existing free plots, revalorization of historic areas, transformation of post-industrial zones in the city areas, control of new emerging investment zones.

One of the weakest point in the high value areas is the disappearance of a "composition factor" in the modern urban planning process and lack of acceptance that eco-aims should for part of the new design. Therefore, in order to achieve a harmonious urban composition, the developers should not only meet the local legal requirements, but also try to include other values. The basic "must" is to establish a sequence of tasks, allowing to logically follow the path to achieve expected aims. The leading idea has to be clear and precisely defined. Nowadays the general aim of the urban planning process, a logic and harmonious location of functions and buildings, it is only very rarely sufficiently precise, and more than often criticized and negated, both by investors and planners, as "a set of rigid rules". Hence the requirement, to show a definite connection between the primary "idea" and the later "on-going" urban planning decisions taken during investment's later stages. It is also very important to place an emphasis on the elements forming the urban characteristics features. 
In order to organize applicable sustainable strategies and procedures, lately some international research programs have been started in Poland. One of them is INTEND -- Integrated Energy Design, a project which aims to provide clear rules showing how these procedures may be applied in countries with various design approaches different levels of sustainable knowledge and education. The other is STEP - dealing with sustainable thermomodernisation of Public Buildings supported by EU and financed by the Norwegian Funds - established in order to calculate benchmarks for the public buildings, as well as start with a wide education process both in the Universities and in the professional levels.

\section{References}

[1] Bielecki C. 1996: Gra w miasto. Warszawa: Fundacja Dom Dostepny

[2] Cielatkowska R. 2001: Nowa jakosc $i$ wartosc $w$ kontekscie architektonicznym. PKN ICOMOS

[3] Ghirardo D. 1999: Architektura po Modernizmie. Torun Wydawnictwo VIA

[4] Giddens A.: 2002 : Nowoczesnosc i tozsamosc. Wydawnictwo Naukowe PWN

[5] Lorens P. 2006: Tematyzacja przestrzeni publicznej miasta. Wydawnictwo Politechniki Gdańskiej

[6] Mortensen P.D. 1996: Introduction. The Copenhagen Spaces. Copenhagen: Architektens Forlag

[7] Myczkowski Z. 2003: Krajobraz wyrazem tozsamosci w wybranych obszarach chronionych w Polsce. Wydawnictwo Politechniki Krakowskiej, Kraków

[8] Myczkowski Z. 2004: Tozsamosc i ochrona krajobrazow niezwyklych. Urbanista no 6

[9] Pound Ch. 2001: Autentycznosc kontynuowana. Tozsamosc miasta odbudowanego. Autentyzm - Integralnosc - Kontynuacja, Gdańsk PKN ICOMOS

[10] Ryńska E. 2004: Srodowiskowy proces inwestycyjny dla architektow. Wydawnictwa Politechniki Warszawskiej, 